\title{
Analysis of Language Errors in Writing Proposals for XI Grade Students at Prima Unggul Vocational School
}

\author{
Anis Fatikah; Budi Setiawan; Sumarwati \\ Indonesian Language Education Master Program, Sebelas Maret University of Surakarta, Indonesia
}

http://dx.doi.org/10.18415/ijmmu.v9i2.3417

\begin{abstract}
This study aims to describe the Indonesian language errors in writing proposals for eleventh grade students of SMK Prima Unggul. The research method used in this research is descriptive qualitative. The form of this research data is in the form of a proposal essay for eleventh grade students of SMK Prima Unggul. Data collection techniques using documentation and interview techniques. The data validity technique is data triangulation and theory triangulation. While, the data analysis technique uses interactive analysis techniques. The results of this study indicate that there are errors in Indonesian, including errors in the use of punctuation marks in the form of errors in the placement of signs (, ) and (. ), errors in the use of the 'sampai dengan' (up to) sign and errors in the use of subchapter markers. Meanwhile, errors at the morphological level are typos and the use of foreign language vocabulary that is not written in italics.
\end{abstract}

Keywords: Language Error; Writing; Proposal

\section{Introduction}

Every human being has different abilities, both in sociological, musical, naturalist, logical, spatial, visual, kinesthetic, interpersonal, intrapersonal, and linguistic fields. All of these abilities have different meanings and characteristics from one another. This research is related to linguistic ability, namely a person's ability in linguistic. Individuals with linguistic potential will be able to understand 4 aspects of language skills such as listening, listening, reading, and writing. Each language skill also has different meanings and characteristics, although they are related to each other.

At the high school level, writing skills have been taught since kindergarten, at that level children are trained to follow letter patterns or thicken letters, if they are fluent they will be trained to the next stage, namely making syllables, making words, sentences, and paragraph. Writing skills are taught up to a higher level of education, namely college. There are many texts including reports, letters, or other scientific writings that require good writing skills. Further, writing for official purposes requires good writing skills. 
Hastuti (2003: 18) defines that someone who has the ability to use two languages interchangeably is called a bilingual. In this regard, Pranowo (2014: 103) also suggests that Indonesian society in general is a bilingual society. Most of the Indonesian people master the first language (B1) the regional language and the second language (B2) Indonesian. Lado (in Chaer and Agustina, 2010: 86) suggests that bilingualism is the ability to use one's language as well as their second language, which technically refers to knowledge of two languages. Writing skills can be classified based on two points of view, first, namely activities in carrying out writing skills and second, namely the results of writing products which are divided into four, namely: narrative essays, expositions, descriptions, and arguments.

In this study, researchers will focus on the product of writing, namely the proposal text, which is a work plan that is used as a work plan an agenda or event. The author examines the proposal essay from eleventh grade students of SMK Prima Unggul. In this study, it will be seen the ability to write student proposal essays, such as the ability to master vocabulary, diction, sentence structure, paragraph formation, logic, and coherent thinking sentence structure. Proposal writing certainly has various aspects of assessment, a proposal that is worth reading pays attention to linguistic rules and the structure of the proposal text. This will facilitate the delivery of the objectives in the proposal to the particular agency, individual, or organization being addressed. In addition, in writing a proposal, the ability to express ideas, thoughts, or feelings to others in a coherent and systematic way will make it easier to make proposals that are worth reading. This is because the proposals made are able to provide information that is easily accepted and can be useful for the community.

Language errors will always exist, especially for those who are learning a language. As a process, language learning is considered very reasonable if errors are found in it. This is in line with the opinion of Dulay et al. (in Yulianto and Mintowati, 2010: 53) which suggests that it is impossible for people to learn a language without making mistakes. Therefore, mistakes are a natural thing or something that is unavoidable in language learning.

Language errors can occur at any linguistic level. The most common language errors occur due to deviations from language rules. Language errors are simply interpreted as the use of language, whether done orally or in writing, which deviates from the rules of language. This is in line with the opinion of Tarigan (1988: 272), who revealed that error is the side that has defects in the student's speech or writing. Complementing the above statement, Dulay, et al. (1982: 277) revealed that error is part of the conversation or composition that deviates from some standard norms (or selected norms) of adult language performance. Language errors made by students are considered a natural thing, but they must be reduced to a minimum. It can be done if the teacher is able to analyze the error carefully and analyze in depth.

Language error analysis can be viewed as a series of activities in collecting, identifying, classifying, explaining, and evaluating language errors. This is in line with the opinion of Tarigan and Sulistiyaningsih (in Setiawati, 2010: 18) who argue that language error analysis is a work procedure commonly used by researchers or language teachers, the analysis is including: activities of collecting error samples, identifying errors contained in the sample, explaining the error, classify the error, and evaluate the seriousness of the error.

This condition cannot be separated from the Indonesian language learning process in schools which is not optimal in helping students to be skilled in writing, especially in learning to write proposals so that there are still many errors found in writing proposals such as inappropriate placement of capital letters and lowercase letters, font sizes, and logos too large, the use of foreign languages that are not italicized, the use of inappropriate punctuation marks, the use of symbols or signs that are not needed in making certain points, and many others errors were found.

Apart from the lack of interest in writing, not honing their writing skills, and the fear of being wrong in writing are the basic problem cause the error in writing. Student in the class also does not know mistakes in writing proposals because the proposals that have been assessed by the teacher are not taken 
back and are not revised by students. Thus, errors in writing are not known to be true by students and this makes mistakes persistent.

Language errors made by students can occur in various fields and this is something that naturally happens. Language errors can occur in various fields, both written and spoken language. Language errors are grouped into certain categories to make it easier to explain. To sharpen students' knowledge of writing, first instill and foster a sense of fun towards literacy, this makes students will continue to hone their writing skills, motivate students not to be afraid of mistakes in writing, because mistakes in writing can be corrected and honed continuously. This, students are expected to be able to have decent writing quality and meet the elements of writing language rules that are in accordance with PUEBI. Furthermore, the tasks that have been assessed by the teacher will be better immediately revised by students so that students will better know where the error is and fix it.

Not only fixing problems that arise from students, the teacher's factor also greatly influences the effectiveness of students in mastering writing skills, especially writing proposals. In some of the problems that have been mentioned previously, the solutions that must be considered by the teacher, the teacher should provide more effective methods and strategies in assembling the proposal writing material, the teacher can invite students to participate in writing training, visit libraries, or visit related museums with language literacy. If the writing learning method is only done with lectures, it will certainly make students bored so that students are not interested in literacy and think writing is boring.

From the problems that have been described above, the researchers are interested in examining the ability to write proposals in vocational students. In this study, it is expected to be able to provide an overview or description of the majority of students in class XI SMK Prima Unggul on their writing skills and provide effective solutions to problems that arise related to language errors that occur in writing proposals. In line, the researchers gave the title of the study, namely "Language Errors in Writing Proposals for XI Grade Students of Prima Unggul Vocational School".

\section{Research Method}

The research method used in this research is descriptive qualitative. In a research method, it is important to know the direction or course of a research. Qualitative research emphasizes data analysis carried out by describing the text and interpreting the meaning (Cresswell, 2015: 31). The form of this research data is in the form of a proposal essay for eleventh grade students of SMK Prima Unggul. Data collection techniques using documentation and interview techniques. The data validity technique in this research is by using data triangulation and theoretical triangulation. While, the data analysis technique uses interactive analysis techniques by applying data collection, data reduction, data analysis and drawing conclusions

\section{Finding and Discussion}

The activity of analyzing the use of language errors in this study is to identify the types of errors in the use of Indonesian in writing proposals for eleventh grade students of Prima Unggul Vocational School. These errors are classified into two areas, namely punctuation and morphological aspects. Considering that there are quite a lot of Indonesian errors found in this study, not all types of errors are described here. The researcher only explained the language errors in writing student proposals as an example. The following are some of the findings of language errors. 


\title{
Errors in Indonesian in terms of punctuation in writing proposals for class XI students of SMK Prima Unggul
}

\author{
Datum 1
}

\section{PENDAHULUAN \\ Latar Belakang}

Menyambut datangnya hari kemerdekaan ke-76 Republik Indonesia pada tanggal 17 Agustus 2019, sebagai bagian dari bangsa Indonesia, maka menjadi kewajiban bagi kita, untuk jasa-jasa pahlawan kita yang sudah memperjuangkan kemerdekaan Republik Indonesia.

In datum 1 above, punctuation errors are found in the 'latar belakang' point and a comma after the word 'kita'. In General Guidelines for Indonesian Spelling or also known PUEBI (Pedoman Umum Ejaan Bahasa Indonesia) the correct punctuation is "A. Latar Belakang". The order in writing subchapters according to PUEBI is capital letters, numbers, lowercase letters, closing bracket numbers, lowercase brackets, numbers in brackets and lowercase letters in brackets. The spelling error in the subchapter in the picture above is the absence of capital letters as a marker for the first sub-chapter in the proposal. While, the punctuation mark (, ) after the word 'kita' is a word decapitation error. The sign (, ) should be removed, so that the sentence is easier to understand.

Datum 2

\begin{tabular}{|c|}
\hline Pengeluaran \\
Karung 10 item : Rp. 20.000 \\
\hline
\end{tabular}

The punctuation error in datum 2 above is the sign ( . ) after Rp. According to PUEBI, after the currency should immediately state the nominal without any dots. The justification for the error is "Rp 20,000 ", in the correct Indonesian language after Rupiah, we should write down the nominal amount immediately. Not many people know about this rule, so errors in the use of punctuation are still often found in writing in various places. This is due to the lack of public knowledge regarding the correct use of language in formal writing.

Datum 3

\begin{tabular}{|l|}
\hline $07.30-08.30$ \\
\hline $08.30-11.30$ \\
\hline
\end{tabular}

The punctuation error contained in datum 3 above is the use of the (-) sign. In stating the word 'sampai dengan' (up to) which indicates time, the correct use of the sign should be the 's.d' sign. in PUEBI, this 's.d' sign has formally become an abbreviation of up to phrase. For this reason, in stating the phrase in Indonesian the correct way is to state it using the 's.d' sign. Through this research, it is hoped that readers can add linguistic insight, especially in terms of using proper punctuation. 
Datum 4

\begin{tabular}{|ll|}
\hline 1. & Macam-macam kegiatan \\
- & Murotal Al-Quran \\
- & Melantunkan sholawat \\
- & Gadroh dan Marawis \\
\hline
\end{tabular}

The error in using punctuation in data 4 above is a marker for the sub-chapter. This error has already been described in data analysis 1 above. After the number subsection, the next subsection should be written in lowercase letters. The justification for the above error is as follows.

\section{Macam-macam kegiatan}
a. Murotal Al-Quran
b. Melantunkan sholawat
c. Hadroh dan Marawis
d. Games

Datum 5

Drs. Mohammad Imam M.Pd.

The punctuation error in datum 5 above is the absence of a sign $($,$) after writing the name. In$ PUEBI, to separate the name and the title after the name is to use a sign (, ). While, the separator between the title before the name with the name is with a sign (. ). In datum 5 above, the use of a sign ( . ) as a title separator before the name and name is correct, while the sign (, ) which should be after the name has not been written by the proposal writer. It becomes important for educators to pay attention to in delivering complex linguistic material and get used to paying attention to the use of punctuation in their writing.

\section{Errors in Indonesian Language Morphologically in writing proposals for class XI students at Prima Unggul Vocational School}

Data 6

\begin{tabular}{|c|c|}
\hline Pembukaan dipanggung pensi & MC \\
\hline $\begin{array}{c}\text { Acara kegiatan pentas drama, tari } \\
\text { tradisional dan moden dance }\end{array}$ & Seksi acara \\
\hline
\end{tabular}

The language error in data 6 above is the writing of the words 'moden' and 'dance'. It seems that there was a writing error in the word 'moden' which should have been written with the word 'modern'. Errors like this are common among people called typos. While, the writing of the word 'dance' is a foreign language vocabulary that should be written in italics to become 'dance'. Although the mistakes above are common among the public, educators need to be careful in correcting student work to minimize the habit of writing errors. Similar to data 4 in subchapter 1 above, the word 'games' is also a foreign language vocabulary that should be written in italics. Educators must be able to minimize errors that occur in the work of these students with the accuracy of an educator. 


\section{Conclusion}

Based on the analysis of the data presented by the researcher above, it can be concluded that language errors in writing proposals for eleventh grade students of SMK PRIMA UNGGUL are including errors in the use of punctuation marks in the form of incorrect placement of signs $(,$,$) and ($.$) , errors in$ the use of the 'sampai dengan' (up to) sign and incorrect use of subsection markers. Meanwhile, errors at the morphological level are typos and the use of foreign language vocabulary that is not written in italics.

\section{References}

Tarigan Henry Guntur. 2008. Menulis Sebagai Suatu Keterampilan Berbahasa. Bandung: Angkasa Bandung.

Dulay, et. al. (1982). Language Two. New York: Oxford University Press.

Yulianto, B.(2011). Penuntun Praktis Berbahasa Indonesia dengan Baik dan Benar. Surabaya: Universitas Negeri Surabaya University Press.

Setyawati, N. (2010). Analisis Kesalahan Berbahasa Indonesia. Surakarta:Yuma Pustaka.

Hastuti, S. (2003). Sekitar Analisis Kesalahan Berbahasa Indonesia. Yogyakarta: Mitra Gama Widya.

Pranowo. (2014). Teori Belajar Bahasa. Yogyakarta : Pustaka Belajar.

Chaer, A., \& Agustina, L. (2010). Sosiolinguistik Perkenal Awal. Jakarta: Rineka Cipta.

Yulianto, B., \& Mintowati, M. (2010). Analisis Kesalahan Berbahasa. Jakarta: Universitas Terbuka.

Cresswell, J. (2015). Riset Pendidikan, Perencanaan, Pelaksanaan, dan Evaluasi Riset Kualitatif dan Kuantitatif. Yogyakarta: Pustaka Pelajar.

\section{Copyrights}

Copyright for this article is retained by the author(s), with first publication rights granted to the journal.

This is an open-access article distributed under the terms and conditions of the Creative Commons Attribution license (http://creativecommons.org/licenses/by/4.0/). 